\title{
Occurrence and Sustenance of Arbuscular Mycorrhizae in Selected Dry Zone Agricultural Lands in Sri Lanka
}

L.I.D. Arachchige ${ }^{1}$, A. Balasuriya ${ }^{1 *}$, L.J. Cseke ${ }^{2}$, M.V. Nathan ${ }^{2}$, M.C. Samarakoon ${ }^{3}$ and J.P.H.U. Jayaneththi ${ }^{4}$

\author{
${ }^{1}$ Department of Plant Sciences, \\ Rajarata University, \\ Anuradhapura, Sri Lanka \\ ${ }^{2}$ Division of Plant Sciences, \\ University of Missouri, \\ Columbia, MO, USA \\ ${ }^{3}$ Department of Biology, Faculty \\ of Science, Chiang Mai \\ University, Chiang Mai 50200, \\ Thailand \\ ${ }^{4}$ Department of Agricultural \\ Engineering and Soil Science, \\ Rajarata University, \\ Anuradhapura, Sri Lanka
}

\section{Correspondence:}

*abhayab2006@gmail.com

iD https://orcid.org/0000-0001-8377-114X

DOI: http://doi.org/10.4038/sljae.v3i1.63

\begin{abstract}
Arbuscular mycorrhizae (AM) are one of the important symbiotic microorganisms that provide a primary natural pathway for soil/plant nutrient transfer. The prevalence of AM on Reddish Brown Earth soils in the dry zone was determined under three agronomic management regimes: least-, moderate- and well-managed at Kiralogama, Puliyankulama, and Medawachchiya, respectively, in the Anuradhapura District. Arbuscular mycorrhizae interactions were evaluated with varieties each; sesame (Sesamum indicum L.), bitter gourd (Momordica charantia L.), cowpea (Vigna unguiculata (L) Walp.), chilli pepper (Capsicum annuum L.) and tomato (Solanum lycopersicum L.), and locallycommon four weed/non-crop species; akmella (Synedrella nodiflora (L.) Gaertn.), balathana (Eleusine indica (L.) Gaertn.), kurakkan (Eleusine coracana (L.) Gaertn.), and wal-rubber (Euphorbia heterophylla L.) in pot experiments. Rhizosphere soils at the well-managed Medawachchiya site recorded the highest number of average live (1312) and dead (2637) spores per $100 \mathrm{~g}$ of soil retained on $125 \mu \mathrm{m}$ sieve compared to the lowest live (459) spores at the least-managed site at Kiralogama. At both Kiralogama and Puliyankulama, live spore counts significantly increased with the progress of Maha rainy season. Increases in plant $\mathrm{P}$ and $\mathrm{Zn}$ concentrations showed strong positive correlations with AM colonisation. Significant differences of both AM colonisation and spore counts were observed in pot experiments depending on the weed/non-crop species and the variety of crops. Akmella (51.2 \%), bitter gourd (var. Black - 69.1\%), Sesame (var. Mali - 76.7 \%) and wal-rubber (76.8 \%) were associated with high levels of AM colonisation as well as soil spore counts.
\end{abstract}

Keywords: Phosphorus, Reddish Brown Earth, Root colonisation, Spore count, Zinc 


\section{Introduction}

Plants take up nutrients using two basic delivery pathways; 1 ) chemical nutrient pathways rely on water soluble nutrient ions during the uptake of water from the environment (Gregory 2006) and 2) biological nutrient pathways rely primarily on soil microbial interactions with plant roots (Lowenfels and Lewis 2010; Cseke et al. 2013). In biological pathways, fundamentally the nutrients are taken up first by the microorganisms which deliver the nutrients directly to the plant roots in exchange for fixed carbon (Larsen et al. 2016; Victor et al. 2017). If well-maintained, these natural systems provide significant increases in plant health and yield over long periods. Thus, many beneficial microorganisms within these systems are important resources for future land management applications (Bhale et al. 2018).

Mycorrhizae are one such group that lives in a symbiotic association of roots of about $90 \%$ of all terrestrial plants (Smith et al. 2014). Arbuscular mycorrhiza (AM) (Glomeromycota) forms a particularly intimate association with plant roots, where the mycorrhizal hyphae penetrate the root cell walls, forming branched structures inside the root cortex cells, called arbuscules, that enhance nutrient exchange (Bolan 1991). Increased nutrient uptake is a consequence of higher soil volume exploration by the mycorrhizal roots via fungal extra-radical hyphae that extend into the soil where they increase the mobilization of poorly mobile soil nutrients like phosphorus (P) and zinc (Zn) (Mackay et al. 2017).

The AM associations increase plant resistance to root and soil borne pathogens, and it has a positive effect on plants under drought conditions to retain moisture around the root zone (Berruti et al. 2016). Arbuscular mycorrhiza reportedly enhances colonisation of introduced populations of beneficial soil bacteria like Azotobacter Beijerinck, Azospirillum Tarrand, et al., Rhizobium Frank, and phosphate solubilizing bacteria around mycorrhizal roots, thereby exerting synergistic effects. In addition, AM can improve soil structure and aggregation through mechanical effects exerted by extra-radical hyphae or through hyphal glycoprotein exudation (Mansfeld et al. 2002).

During land fallowing, AM presence and activity may be sustained through the growth of cover crops and weed species, where AM spore levels can be 
maintained for future growing seasons. However, evidence suggest that AM fungal communities vary from place to place, and depend on the plant species and varieties being grown, as well as specific management practices (Plenchete et al. 1983; Habate and Manjunath 1991). Further, the presence or abundance of AM is invariably decided by the weather and climatic factors of a given region. Many studies of plant-AM interactions and field managements have been conducted in Asia, with a few in Sri Lanka (e.g. Palipane and Bandara 1985; Mala et al. 2010; Pathirana and Yapa 2020).

Dry zone (DZ) (Panabokke 1996) constitutes about one-third of the major crop growing area in Sri Lanka. Crop production limitations are aplenty in the DZ due to extremes in water availability during the wet (Maha) and dry (Yala) seasons (Burchfield and Gilligan 2016). Conventionally, such environmental challenges are overcome with added chemical fertilizers and continuous cropping systems, supplemented by pesticides. Recently, there are concerns about the over-dependence on such inputs, as they have become costly and unaffordable at times, and more importantly due to the increasing number of unconfirmed connections of chemical inputs to chronic kidney disease of unknown etiology (CKDU) (Jayasumana et al. 2014). These concerns increase pressure towards the reliance on sustainable agriculture, with the aim of reducing dependence on chemical inputs and moving into integrated crop management systems. One approach to address these concerns is to harness the biological systems that are naturally available in the form of AM associations. The long dry spells prevalent in the Anuradhapura District may affect the availability of such beneficial associations. Presently, it is not possible to ascertain the status of mycorrhizal associations in and around DZ crops or weeds due to the absence of relevant research findings.

Therefore, we aimed to assess the prevalence, sustenance, and benefits of $\mathrm{AM}$ in DZ under different management practices and their associations with different crop and weed/non-crop species in considered agro-ecosystems in Anuradhapura district, Sri Lanka. 


\section{Materials and Method}

\section{Field experiments}

\section{Locations and site selection}

Field experiments were conducted at three field sites 25-30 km apart; Kiralogama (KIR), Puliyankulama (PUL) and Medawachchiya (MED) in Anuradhapura District as detailed in Table 1 . The soil type in this region is reddish brown earth (Rhodustalfs) (Panabokke 1996) and was located on well-drained topographies. Each sampling site was left fallowed during the preceding dry season (2-3 months), natural weed populations that are common to the agro-ecosystem of the selected regions. Management practices differed at each site as: least-, moderate, and well-managed (Table 1).

Weekly rainfall data, covering July to December, were collected from the meteorological observatories nearest to the sites: Mahailluppallama, Puliyankulama, and Vavuniya for KIR, PUL, and MED, respectively. Bi-weekly cumulative rainfall data were calculated for each corresponding station, and previous to each reference soil sampling date.

At each site, three $1 \mathrm{~m}^{2}$ plots were marked. Soil samples were collected three times in each site as summarized in Table 1.

Table 1. The field site locations, management practices and soil sampling intervals

\begin{tabular}{|c|c|c|c|}
\hline \multirow{2}{*}{ Description } & \multicolumn{3}{|c|}{ Field site } \\
\hline & Kiralogama (KIR) & Puliyankulama (PUL) & Medawachchiya (MED) \\
\hline Location & $8^{\circ} 11^{\prime} 54.2^{\prime \prime} \mathrm{N} 80^{\circ} 22^{\prime} 15.6 " \mathrm{E}$ & $8^{\circ} 22^{\prime} 16.3^{\prime \prime} \mathrm{N} 80^{\circ} 25^{\prime} 12.0^{\prime \prime} \mathrm{E}$ & $8^{\circ} 32^{\prime} 36.2^{\prime \prime} \mathrm{N} 80^{\circ} 29^{\prime} 20.8^{\prime \prime} \mathrm{E}$ \\
\hline $\begin{array}{l}\text { Evidence of field } \\
\text { management }\end{array}$ & $\begin{array}{l}\text { Least - previous wet } \\
\text { season with maize, no } \\
\text { crop during the dry season } \\
\text { with only free growing } \\
\text { voluntary weeds }\end{array}$ & $\begin{array}{l}\text { Moderate - previous wet } \\
\text { season with home garden } \\
\text { crops, no crop during the } \\
\text { dry season with only free } \\
\text { growing voluntary weed } \\
\text { cover with occasional } \\
\text { slashing as an in the } \\
\text { farmer's field }\end{array}$ & $\begin{array}{l}\text { Well-managed - continuous } \\
\text { low-input-cropping of wet } \\
\text { and dry seasons with some } \\
\text { voluntary weeds }\end{array}$ \\
\hline Soil sampling(3)* & Day - $0 ; 35 ; 86$ & Day - 0; 34; 76 & Day $-0 ; 35 ; 81$ \\
\hline
\end{tabular}

*first in the dry season (prior to the onset of rains - day 0 ), second sampling after approximately one month from first and after commencement of rains, and third sampling, approximately three months into the rainy season.

Arbuscular mycorrhiza spore counts (AMSC) and soil chemical analyses

Soil samples were collected from five diagonal points avoiding any overlap in the subsequent sampling within each 1 $\mathrm{m}^{2}$ plot and mixed to obtain a representative sample in each. Nine soil samples were collected from each 
location on three rounds during the study.

For spore counts, soil samples were collected at each site at a depth of 0-5 $\mathrm{cm}$, after the removal of weeds, and were composited, sieved through a $2 \mathrm{~mm}$ mesh to obtain $5 \mathrm{~g}$ soil samples per plot. Soil spore assays were conducted using sucrose centrifugation method (Ianson and Allen 1986) adapted to use SucroseCalagan solution, centrifuged at 2500 rpm for 20 minutes, and sieved using $125 \mu \mathrm{m}$ bottom sieve to separate AM spores. The live spores were distinguished from the dead ones using their surface characteristics: light brown, shiny surfaced, containing clearly visible lipid globules, where the dead were dark black, and never germinated (Hijri et al. 2002). The spores were counted with light microscopy on a microscope grid slide.

For chemical analyses, soil samples were collected from a depth of 5-15 cm and allowed to air dry for 4-5 days. These samples were sieved using $2 \mathrm{~mm}$ mesh and analysed for soil $\mathrm{pH}$ (1:2.5, soil:water) (Darmakeerthi et al. 2007) and soil available $\mathrm{P}$ (Olsen et al. 1954). Soils sieved through $80 \mu \mathrm{m}$ mesh were used for the analysis of available $\mathrm{Zn}$
(Darmakeerthi et al. 2007). Soil microbial biomass carbon analyses were done following Darmakeerthi et al. (2007). All the laboratory experiments were conducted at the Faculty of Agriculture, Rajarata University of Sri Lanka (RUSL), Anuradhapura.

\section{Weed species and root Arbuscular mycorrhza colonisation}

Initially, all the weeds available within 1 $\mathrm{m}^{2}$ plots at each site were manually removed and allowed to re-grow under natural conditions. A $50 \mathrm{~cm}^{2}$ wooden quadrat was dropped randomly inside each $1 \mathrm{~m}^{2}$ plot to assess the frequency and density of each weed species (Justina et al. 2012).

\section{Pot experiments}

\section{Arbuscular mycorrhiza populations under protected conditions}

Topsoil (5-15 cm) with zero initial vegetation, and exposed to natural conditions, collected from the faculty research farm, was used as a potting medium within the protected house (consisted only of protected walls, and no roof), through the three-month experimental period. Soil samples were collected in triplicate for soil 
characterization, which included average AMSCs, $\mathrm{pH}$, available $\mathrm{P}$ and $\mathrm{Zn}$, and microbial biomass carbon at the beginning and at the end of the experiment during the wet season (Maha - 2015).

Arbuscular mycorrhiza root colonisation (AMRC) was assessed using $2.5 \% \mathrm{KOH}$ and trypan blue staining method (Phillips and Hayman 1970). Counts of AM associations were assessed using light microscopy at $100 \mathrm{X}$ and $400 \mathrm{X}$ magnifications.

\section{Arbuscular mycorrhiza populations of selected weed species}

Species selection was made based on the abundance in the area, availability of viable seeds for propagation, and significance. Four weed/non-crop species were selected as, akmella (Synedrella nodiflora (L.) Gaertn.), balathana (Eleusine indica (L.) Gaertn.), kurakkan (Eleusine coracana (L.) Gaertn.), and wal-rubber (Euphorbia heterophylla L.).

Eighteen pots (10 L each) including the controls were filled with pre-analysed (for available $\mathrm{P}, \mathrm{Zn}$, soil $\mathrm{pH}$, microbial biomass carbon, and AMSC) soils from PUL. Mature seeds (6-7 for broad leaved;
8-10 for grasses) of the above species were introduced to pots in triplicate. The numbers of seeds per pot were selected based on their growth forms, size, and potential viability. Pots were watered on non-rainy days to maintain the soil moist throughout, taking care to remove any volunteer weeds. Negative control was maintained totally free of weeds, while the positive control was allowed free weed growth.

Plants were sampled destructively (at $50 \%$ flowering). The roots were washed, and the root-tips were separated for processing for AMRC (Phillips and Hayman, 1970). Soil from each pot was subjected to chemical analyses for available $\mathrm{P}, \mathrm{Zn}$, soil $\mathrm{pH}$, microbial biomass carbon, and AMSC.

\section{Arbuscular mycorrhiza populations of selected crops}

Sesame (var. MI-1, Mali, Uma), cowpea (var. Bombay, Vijaya, Waruni), bitter gourd (var. Black, MC-43, Thinnaweli), chilli pepper (var. HYW, MI-1, MI-2), and tomato (var. Larisa and Thilina) were selected.

The number of seeds per variety/pot were based on the final form of the plant. Three seeds each of tomato, bitter gourd, 
and cowpea; seven seeds of sesame, and five seeds of chilli were used. Pots/plants were watered on non-rainy days to maintain the soil moist, through the experimental period, and kept free of any volunteer weeds/plants. Short duration crops (cowpea and sesame) were destructively sampled for counting AMRC at $100 \%$ flowering, while the long duration crops (bitter gourd, tomato, and chilli) were sampled at 50\% flowering. At the time of destructive sampling of plants, soil from each pot was subjected to chemical analysis for available $\mathrm{P}, \mathrm{Zn}$, soil $\mathrm{pH}$, microbial biomass carbon, and AMSC.

\section{Statistical data analysis}

Data were analysed using the statistical analysis system (SAS) package (version 9.0). For the analysis of temporal and spatial behaviour of AM, PROC GENMOD was used to fit a Poisson regression. ANOVA was used to test AM colonisation among crop/weed species and varieties. Mean separation was performed using the least significant difference (LSD) and Tukey's test. Relationships between AMRC \% and plant $\mathrm{P}$ and $\mathrm{Zn}$ nutrient concentration were tested using Pearson correlation analysis.

\section{Results and Discussion}

Arbuscular mycorrhiza populations vs seasonal rainfall, natural weed cover, and management practices

Rhizosphere soils from the wellmanaged (MED) and least managed (KIR) locations recorded the highest and lowest live spore counts as; 1340, 1380, 1217, and 213, 567, $597100 \mathrm{~g}^{-1}$ soil, respectively at the three rounds (Table 2). Live spore counts at PUL were increased with time and cumulative rain. All sites recorded low initial live spore counts and increased significantly at KIR ( $p=0.05)$ and PUL ( $p=0.05)$ when changed from dry to wet season (Fig. 1). Number of dead spores at all three sites showed a significantly decreasing trend with each successive round, where significant differences between the first and the third were observed at KIR ( $p=$ 0.0007), PUL ( $p=0.0001)$, and $\operatorname{MED}(p=$ 0.01) (Table 2 and Fig. 1).

At PUL, there was a high weed population with a number of creeping weed species (i.e. Evolvulus nummularius (L.) L., Desmodium trifolium (L.) DC.) which provided extended coverage on the soil surface, possibly adding more protection against exposure to desiccation and sunlight during the preceding dry season. 
Table 2. Mean AMSC of rhizosphere soils under natural field conditions

\begin{tabular}{|c|c|c|c|c|c|c|c|c|c|c|}
\hline \multirow{2}{*}{ Description } & \multicolumn{2}{|c|}{ Collection 1} & \multicolumn{2}{|c|}{ Collection $2^{\dagger}$} & \multicolumn{2}{|c|}{ Collection $3^{\dagger}$} & \multicolumn{4}{|c|}{ Increase/Decrease $\%^{\ddagger}$} \\
\hline & Live & Dead & Live & Dead & Live & Dead & Live & Dead & Live & Dead \\
\hline & & & & & & & \multicolumn{2}{|c|}{ From 1-2 } & \multicolumn{2}{|c|}{ From 1-3 } \\
\hline KIR & & & & & & & \multicolumn{2}{|c|}{ (35 days) } & \multicolumn{2}{|c|}{ (86 days) } \\
\hline Spores $100 \mathrm{~g}^{-1}$ soil & 213 & 2507 & $567^{\mathrm{ab}}$ & $2480^{a}$ & $597^{b}$ & $760^{a}$ & 166 & -1 & 180 & -70 \\
\hline Per 2 weeks $\S$ & 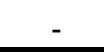 & 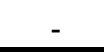 & - & - & - & - & 66.3 & -0.4 & 29.3 & -11.3 \\
\hline$\overline{\text { PUL }}$ & & & & & & & \multicolumn{2}{|c|}{ (35 days) } & \multicolumn{2}{|c|}{ (81 days) } \\
\hline Spores $100 \mathrm{~g}^{-1}$ soil & 300 & 2660 & $533^{\mathrm{ab}}$ & $1827^{b}$ & $680^{\mathrm{b}}$ & $1133^{b}$ & 78 & -31 & 127 & -57 \\
\hline Per 2 weeks§ & - & - & - & - & - & - & 31.1 & -12.5 & 21.9 & -9.9 \\
\hline$\overline{\text { MED }}$ & & & & & & & \multicolumn{2}{|c|}{ (34 days) } & \multicolumn{2}{|c|}{ (76 days) } \\
\hline Spores $100 \mathrm{~g}^{-1}$ soil & 1340 & 3520 & $1380^{\mathrm{a}}$ & $2500^{\mathrm{b}}$ & $1217 \mathrm{a}$ & $1893^{a}$ & 3 & -29 & -9 & -46 \\
\hline Per 2 weeks ${ }^{\S}$ & - & - & - & - & - & - & 1.2 & -11.6 & -1.7 & -8.4 \\
\hline
\end{tabular}

Soils under low-chemical input management showed higher AM spore populations compared to soils under conventional (high-chemical) input management (Douds et al. 1995) and remained similar in MED (low-inputmanagement). Brundrett and Abbott (1994) observed significant decreases in spore diversity, the amount of viable mycelium, and colonisation under reduced ground cover possibly similar to KIR with scanty ground cover, allowing some sun scorch and desiccation. In addition, the loss of plant cover can lead to solar oxidation near the soil surface, reducing the viability of spores, as well as loss through erosion during heavy rains, which can wash spores away
(Miller 1979; Powell 1980; Bellgard 1993).

Weather conditions at 4, 8 , and 12 weeks prior to the first round of spore counts remained mostly dry, likely contributing to the low live and very high dead AM spores present in the first round across the three sites. It can also be assumed that lack of sustenance contributed to the death of the majority of spores from the previous season (Pigott 1982). The significant decrease in dead spores is only possible with reduced rates of live AM spore deaths and the degradation of already dead spores (Chandra and Kehri 2006). 

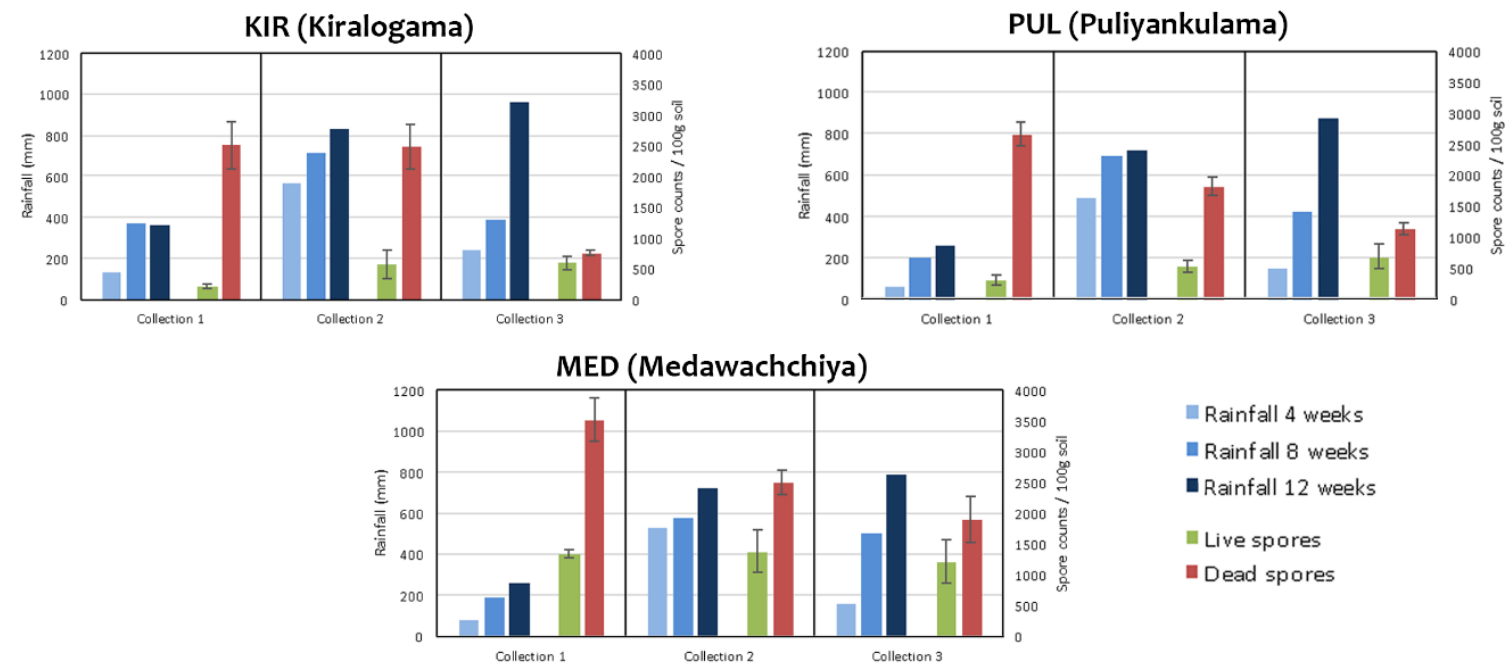

Figure 1. AMSC and the cumulative rainfall at the three field sites.

Strong positive correlations were found between $10^{\text {th }}$ and $12^{\text {th }}$ week cumulative rainfall and the live AMSC at KIR, since initiation of the experiment $(\mathrm{r}=0.66$ at $p$ $=0.05)$. Strong positive relationships were found between cumulative rainfall and the numbers of live spores at $10^{\text {th }}(r$ $=0.77$ at $p=0.01)$ and $12^{\text {th }}(\mathrm{r}=0.92$ at $p$ $=0.01$ ) week at PUL. At MED, the relationship between live spores and cumulative rainfall did not show any significance at similar durations. Strong negative relationships between cumulative rainfall and dead AMSC were observed at 10 weeks in PUL $(r=0.77$ at $p=0.002)$ and MED ( $\mathrm{r}=0.86$ at $p=$ $0.0001)$, at 12 weeks in $\operatorname{KIR}(\mathrm{r}=0.42$ at $p$ $=0.05), \operatorname{MED}(\mathrm{r}=0.81$ at $p=0.001)$ and PUL ( $\mathrm{r}=0.92$ at $p=0.0001)$. These suggest that there was a strong relationship between cumulative rainfall and the availability of dead AMSC in a given soil environment. Therefore, under natural favourable conditions, about 10 to 12 weeks of rainfall could significantly contribute to the build-up of natural reserves of viable AM spores, while reducing their dead counts.

The rainfall at MED was heavy from time to time, and particularly in the latter segment of the experiment (December), it received very high rainfall leading to minor floods (personal observations). Kaushal (2002) made similar observations working with Acasia Mill. in India, where excess soil moisture, corresponding to our results in the $03^{\text {rd }}$ collection at the MED site, resulted in a decrease in spore population and root colonisation. 
The prevalence of AM under DZ land management systems has increased with continued rainfall and crop/weed growth. The presence of AM under DZ land management practices are sustained by selected weed species during fallow periods, but additional experiments are needed to confirm. Physical, chemical, and biological soil properties may exhibit changes when soil loses its natural microbial communities, typically caused by mechanical disturbance or when conventional chemical agricultural practices are imposed; because soil microbial communities are one of the main factors controlling the transformation of organic matter to accessible nutrition in soils (Lejon et al. 2005). Monitoring microbial populations (particularly that of AM), precipitation, and the physicochemical properties of soils can be useful tools to indicate the state of a disturbance at different sites (Pagano et al. 2011).

Different representative weed species showed considerable variations in their AMRC. High potentials in promoting the growth of AM were exhibited by thunessa (Cyperus iria) (51.7\%), being the highest; pututhana (Dactyloctenium aegyptium) (31.7\%), guinea grass (Panicum maximum) (25.3\%), and monarakudumbiya (Vernonia cineria) (13.3\%). The lowest (3.3\%) was recorded in both maduruthala (Ocimum tenuiflorum) and thunhiriya (Schoenoplectus grossus) species (Table 3).

Table 3. Arbuscular mycorrihza root colonization \% of commonly found field collected weed species

\begin{tabular}{llc}
\hline Type & Weed species & AMRC \% \\
\hline Broad leaves & Polpala (Aerva lanata (L.) A. L. Juss. ex Schultes) & $4.0^{\mathrm{e}}$ \\
& Monarakudumbiya (Vernonia cineria (L.) Less.) & $13.3^{\mathrm{d}}$ \\
& Maduruthala (Ocimum tenuiflorum L.) & $3.3^{\mathrm{e}}$ \\
Grasses & Guinea grass (Panicum maximum Jacq.) & $25.3^{\mathrm{c}}$ \\
& Pututhana (Dactyloctenium aegyptium (L.) Willd.) & $31.7^{\mathrm{b}}$ \\
Sedges & Thunessa (Cyperus iria L.) & $51.7^{\mathrm{a}}$ \\
& Thunhiriya (Schoenoplectus grossus (L.f.) Palla) & $3.3^{\mathrm{e}}$ \\
\hline
\end{tabular}

Means within the column, followed by the same letter are not significantly different at $p<0.05$.

This shows the variability in $\mathrm{AM}$ colonisation among different plant/weed species under the same natural conditions, signifying the influence of plant genotype as observed by Krishna et al. (1985). Thus, it can be concluded that not all weed species are efficient in supporting AM populations. 
Whereas, weeds such as thunessa or pututhana do have the potential to sustain AM populations during fallow periods, but it is necessary to consider their potential to become invasive weed species in the crop fields (i.e. thunessa).

\section{Arbuscular mycorrhiza populations}

\section{benefit under selected weed species}

Initial AMSC of the collected soil, in the absence of any vegetation had an average of 200 (live) and 2320 (dead) spores $100 \mathrm{~g}^{-1}$ soil (Table 4). The negative control treatment, which was maintained free of vegetation, at the end of approximately three months of rainy weather recorded an average of 173 live and 1013 dead spores accounting for reductions in both live (13.5\%), which was not significant, and dead (56.3\%) spores, with a strongly significant $(p=$ 0.0001) difference (Table 4).

When compared with the negative control, the increase of live AMSC $(453.5 \%)(p<0.0001)$ and the reduction in dead spores $(41.9 \%)(p=0.001)$ in the positive control (with natural weed cover) were both significant (Table 4). In the total absence of any inputs through the entire 3 months, the gain in $\mathrm{AM}$ population is only possible due to multiplication on the roots of natural weeds that grew as voluntary weeds/plants with the positive control.

Table 4. Mean initial and final Arbuscular mycorrhza spore count under zero and natural weed cover in pot trial

\begin{tabular}{ccc}
\hline \multirow{2}{*}{ Time } & \multicolumn{2}{c}{ AMSC 100 g g $^{-1}$ soil } \\
\cline { 2 - 3 } & Live & Dead \\
\hline Initial soil sampling & $200^{\mathrm{a}}$ & $2320^{\mathrm{a}}$ \\
\hline $\begin{array}{c}\text { Zero weed cover } \\
\text { \% Decrease under } \\
\text { zero weeds }\end{array}$ & $173^{\mathrm{a}}$ & $1,013^{\mathrm{b}}$ \\
\hline $\begin{array}{c}\text { Natural weed cover } \\
\text { \% Increase/ } \\
\text { Decrease under } \\
\text { weed cover }\end{array}$ & -13.5 & -56.3 \\
\hline
\end{tabular}

After the growing of selected weed species, the rhizosphere soils yielded live and dead spore populations ranging from $280-493$ and $720-1586$ spores 100 $\mathrm{g}^{-1}$ soil, respectively (Table 5). The highest live and the lowest dead spore counts were found in soils from pots with akmella $(p<0.05)$, while the lowest live spores and highest dead spores were recorded in soils from pots with kurakkan. Various types of AM spores with colours (ranging from yellowish light brown to dark brown) and with shapes (ranging from oval to irregular) were found in the rhizospheric soils of each given species, probably representing different developmental stages. A high percentage of AMRC was found in wal rubber and akmella $(76.77 \%$ and $51.22 \%$, respectively) 
(Table 5 and Plate 2). Such weed species could play a positive role in agricultural systems in sustaining the natural mycorrhizal populations.

A low percentage of AMRC was found in the monocotyledonous weed/non-crop species, balathana (5.4\%) and kurakkan (14.33\%). This could be probably due to their affinity with symbiotic bacterial species in preference to fungal species (Lowenfels and Lewis 2010). Justina et al. (2012) in their observations inferred that mycorrhizal infection is an important factor in determining which weeds could be associated with various crop fields. This leaves us with an option to manipulate/monitor, which weed species to be promoted in order to sustain AM populations in crop fields during fallow periods.

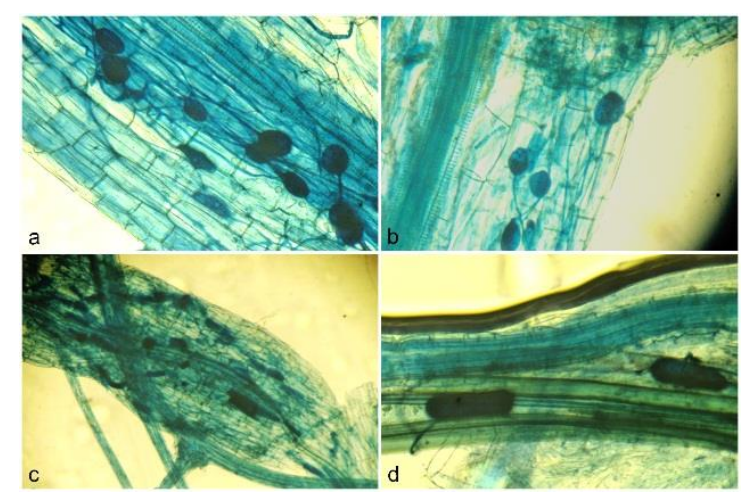

Plate 1: AMRC among selected weed species. a) wal rubber; b) akmella; c) kurakkan; d) balathana. Magnifications: a,b,d $=400 \mathrm{X}, \mathrm{c}=100 \mathrm{X}$.
Unfortunately, mycorrhizal populations can be negatively influenced by many factors, resulting from either natural

Table 5. Arbuscular mycorrhiza root colonization $\%$ of selected weed species and their associated mean spore count

\begin{tabular}{|c|c|c|c|}
\hline \multirow[t]{2}{*}{ Weed Species } & \multirow{2}{*}{$\begin{array}{c}\text { AMRC \% } \\
(n=27)\end{array}$} & \multicolumn{2}{|c|}{$\begin{array}{l}\text { AMSC } 100 \mathrm{~g}^{-1} \text { soil } \\
(\mathrm{n}=9)\end{array}$} \\
\hline & & Live $^{\dagger}$ & $\operatorname{Dead}^{\dagger}$ \\
\hline $\begin{array}{l}\text { Wal-rubber- } \\
\text { E. heterophylla }\end{array}$ & $76.8^{a}$ & $320^{b}$ & $1240^{\mathrm{b}}$ \\
\hline $\begin{array}{l}\text { Akmella - } \\
\text { S. nodiflora }\end{array}$ & $51.2^{b}$ & $493^{a}$ & $720^{d}$ \\
\hline $\begin{array}{l}\text { Kurakkan - } \\
\text { E. coracana }\end{array}$ & $14.3^{c}$ & $280^{\mathrm{b}}$ & $1586^{\mathrm{a}}$ \\
\hline $\begin{array}{l}\text { Balathana - } \\
\text { E. indica }\end{array}$ & $5.4^{\mathrm{d}}$ & $313^{b}$ & $1253^{b}$ \\
\hline Control & - & $173^{c}$ & $1013^{c}$ \\
\hline
\end{tabular}

† Compare these with the original 200 and 2320 , live and dead spores $100 \mathrm{~g}^{-1}$ soil.

Means within the column, followed by the same letter are not significantly different at $p<0.05$.

processes or human activity. These destructive processes include intense fires (Klopatek et al. 1988; WicklowHoward 1989), exposure of subsurface soil to erosion (Day et al. 1987; Habte 1989) or the activity of burrowing animals (Koide and Mooney 1987). Human activities, which harm mycorrhizae include; topsoil disturbance and stockpiling (Rives et al. 1980), and clear-cut logging (Perry et al. 1987). Damaging agricultural factors that affect AM include, tillage (Evans and Miller 1988), long fallow periods (Thompson 1987), and soil compaction 
(Wallace 1987), growth of nonmycorrhizal crops, biocide application (Haas et al. 1987; Fontanet et al. 1998), flooding (Nopamornbodi et al. 1987), etc. All these processes contribute to hinder the establishment of AM and colonisation, but they could be supplemented through an improved understanding of what plant species could help support soil communities.

\section{AM populations benefit under selected crops/varieties}

This experiment used different crop species and varieties commonly grown in Sri Lanka, in soil (from PUL), which contained 200 live and 2320 dead AM spores. At the end of the experimental period their rhizospheric soils yielded live and dead spore densities ranging from 381-832 and 846-1604 spores 100 $\mathrm{g}^{-1}$ soil, respectively (Table 6). The highest average live spore counts were found in soils from pots containing sesame (832), suggesting a highly reactive relationship between $\mathrm{AM}$ and sesame. Low live (381) and the lowest dead (846) spore counts were found in soils from pots with tomato, indicating a very weak affinity of AM towards tomato. The highest dead spores recorded from pots of chilli (1604) may have been due

to an unfavourable reaction of the crop towards AM (Table 6).

Crop species showed a wide variation of AM colonisation dependent on species/varieties (Table 6). Further, differences in AMRC can be found among plant species of the same family (Troeh et al. 2003). Survival of AM in soil can be affected by the presence or absence of crops and the species/variety of crops being grown. Chandra and Kehri (2006) reviewed that AM does not have marked host specificity, though the hosts can differ in the extent of benefits gained from association with a particular symbiont.

Table 6: Arbuscular mycorrhiza root colonization \% of selected crop species and the associated mean spore count

\begin{tabular}{lccc}
\hline \multirow{2}{*}{$\begin{array}{l}\text { Crop } \\
\text { species }\end{array}$} & $\begin{array}{c}\text { AMRC \% } \\
(\mathbf{n}=\mathbf{2 7})\end{array}$ & \multicolumn{2}{c}{$\begin{array}{c}\text { AMSC 100 } \mathbf{~}^{-1} \\
\text { soil }(\mathbf{n}=\mathbf{9})\end{array}$} \\
\cline { 3 - 4 } & Live $^{\dagger}$ & Dead $^{\dagger}$ \\
\hline Sesame & $70.5^{\mathrm{a}}$ & $832^{\mathrm{a}}$ & $1375^{\mathrm{a}}$ \\
Bitter gourd & $61.2^{\mathrm{b}}$ & $554^{\mathrm{b}}$ & $1457^{\mathrm{a}}$ \\
Cowpea & $27.5^{\mathrm{c}}$ & $608^{\mathrm{b}}$ & $1372^{\mathrm{ab}}$ \\
Chilli & $11.8^{\mathrm{d}}$ & $554^{\mathrm{b}}$ & $1604^{\mathrm{a}}$ \\
Tomato & $7.1^{\mathrm{e}}$ & $381^{\mathrm{c}}$ & $846^{\mathrm{c}}$ \\
Control & - & $173^{\mathrm{d}}$ & $1013^{\mathrm{bc}}$ \\
\hline † Compare these with the original 200 and 2320, \\
live and dead spores 100 g-1 soil. \\
Means within the column, followed by the same \\
letter are not significantly different at $p<0.05$. \\
While the extent of root colonisation and \\
responsiveness to AM are known to \\
differ from one plant species to another, \\
much less is known about the differences \\
among genotypes within a plant species.
\end{tabular}


The tests using different varieties provided evidence that sesame var. Mali, cowpea var. Waruni, bitter gourd var. Black, and chilli var. MI-2, recorded the highest AMRC $(76,33,69$, and 15\%, respectively at $p<0.05$ ) compared to the rest of the varieties (Table 7 and Plate 2).

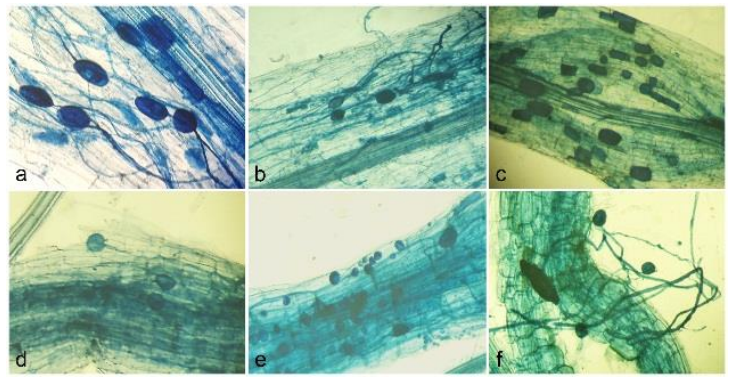

Plate 2: AMRC in different crop varieties. Sesame var. a) mali, b) MI-1; cowpea var. c) bombay, d) waruni; bitter gourd var. e) black, f) MC-43. Magnifications: $\mathrm{a}=400 \mathrm{X}, \mathrm{b}, \mathrm{c}, \mathrm{d}, \mathrm{e}, \mathrm{f}=100 \mathrm{X}$

Table 7. Arbuscular mycorrhiza root colonization among crop species/varieties

\begin{tabular}{cccccccccc}
\hline \multicolumn{2}{c}{ Sesame } & \multicolumn{2}{c}{ Cowpea } & \multicolumn{3}{c}{ Bitter gourd } & \multicolumn{2}{c}{ Chili } & \multicolumn{2}{c}{ Tomato } \\
\hline Variety & AM \% & Variety & AM \% & Variety & AM \% & Variety & AM \% & Variety & AM \% \\
\hline MI-I & $71.9^{\mathrm{b}}$ & Bombay & $30.2^{\mathrm{a}}$ & MC-43 & $54.9^{\mathrm{c}}$ & MI-1 & $12.6^{\mathrm{b}}$ & Thilina & $6.8^{\mathrm{a}}$ \\
Uma & $62.8^{\mathrm{c}}$ & Wijaya & $19.1^{\mathrm{b}}$ & Thinnaweli & $59.7^{\mathrm{b}}$ & MI-2 & $15.7^{\mathrm{a}}$ & Larisa & $7.4^{\mathrm{a}}$ \\
Mali & $76.7^{\mathrm{a}}$ & Waruni & $33.1^{\mathrm{a}}$ & Black & $69.1^{\mathrm{a}}$ & HYW & $7.1^{\mathrm{c}}$ & & \\
\hline
\end{tabular}

Means within the column, followed by the same letter are not significantly different at $p<0.05$.

Both tomato varieties had very low AMRC (6-7\%), while all varieties of sesame had very high levels (62-76\%). These results suggest that careful selection of specific crop species could contribute to promote AM populations and there is potential in the choice of crop species/varieties in the sustenance of AM under DZ land management systems.

\section{Arbuscular mycorrhiza root colonization for the uptake of immobile soil nutrients}

No correlation was found between AMRC and/or AMSC with soil $\mathrm{pH}$ within the range of pH 6-8. Similarly, Akond et al. (2008) reported that there was no correlation between AM colonisation and the soil $\mathrm{pH}$ in their study on vegetable crop plants in Bangladesh. There was also no correlation between soil microbial biomass carbon and AMSC. At the MED site (Table 8), which consistently recorded very high live and dead spores, the microbial biomass carbon was low (0.59 $\left.\mathrm{mgkg}^{-1}\right)$. Ideally, soil samples should have been incubated for seven days before the analysis of soil microbial biomass carbon (Darmakeerthi et al. 2007). The soil sample in this study were incubated only for three days due to limitations imposed on time, which may have influenced the results. 
Many studies have demonstrated that the primary benefit of mycorrhizal symbiosis to the plant is improved $\mathrm{P}$ nutrition (Fitter and Merryweather 1992; Mackay et al. 2017). However, only a low but positive significant correlation ( $r=0.50)$ was observed between AMRC and the change in $\mathrm{P}$ concentrations $(\Delta \mathrm{P})$ in the soil (Fig. 2). The lowest $\Delta \mathrm{P}$ of 27 was observed in the control pots where there was a total absence of plants and with only very low counts of live AM spores (in a range from 173 to 200). The highest $\Delta \mathrm{P}$ was associated with higher AMRC, except in the case of cowpea (data not shown). In leguminous plants like cowpea, high $\mathrm{P}$ requirements are attributed to nodulation and to $\mathrm{N}_{2}$ fixation processes (Barea and ÁzcónAguilar, 1983). Islam et al. (1980) also observed that inoculation with mycorrhizal fungi increased nodulation, nitrogen fixation, and utilization efficiency of rock phosphate in cowpea in pot experiments though these results were not confirmed at field level.

The ability of AM to enhance host-plant uptake of relatively immobile nutrients, $P$ in particular, and several other micronutrients, is the most recognized beneficial effect of mycorrhizae (Mackay et al. 2017). In this study, correlation analysis showed a positive correlation $(\mathrm{r}$
$=0.75$ ) between AMRC and plant $P$ levels (Fig. 2). The highest amounts of plant $P$ (59.7-71.7 $\mathrm{mgkg}^{-1}$ ) were recorded in sesame, bitter gourd, wal rubber, and akmella where the AMRC was highest (51.2-76.8\%), while the lowest plant $\mathrm{P}$ (30.1-43.1 $\mathrm{mgkg}^{-1}$ ) was recorded in chilli, tomato, and balathana where the AMRC was the lowest (5.4-15.7\%) (Fig. 2). Overall, soil available $P$ decreased with time in the presence of respective plant species (Table 8), indicating that $P$ is mobilized from soil and is ending up in the plant material. Studies on the rate of absorption of $\mathrm{P}$, using ${ }^{32} \mathrm{P}$ have revealed that the absorption of $\mathrm{P}$ by mycorrhiza in association with roots was about twice those of control roots (Cress et al. 1979). Heap and Newman (1980) showed that mycorrhizae increased $P$ transport from soil to plants but that the mechanism of transport is only beginning to be understood (Berruti et al. 2016). Conversely, Vivekanandan and Fixen (1991) demonstrated a considerable reduction in AMRC when $P$ fertilizers are used in cropping systems. Other studies suggest that the addition of rock phosphate and organic manure to AM fungal plants are low cost and ecologically sound alternatives to intensive use of $\mathrm{P}$ fertilizers for various crops (Alloush et al. 2000; Mackay et al. 2017) 
Table 8. Soil chemical characteristics at selected field sites

\begin{tabular}{lcccccccc}
\hline \multirow{2}{*}{ Site } & \multicolumn{2}{c}{$\mathbf{p H}$} & \multicolumn{2}{c}{ Available P (mgkg-1) } & \multicolumn{2}{c}{ Available Zn (mgkg-1 } & \multicolumn{2}{c}{ Biomass C (mgkg-1 } \\
\cline { 2 - 9 } & Initial & Final & Initial & Final & Initial & Final & Initial & Final \\
\hline KIR & 6.4 & 7.1 & 65.2 & 29.8 & 6.9 & 3.5 & 1.3 & 0.9 \\
PUL & 6.8 & 6.8 & 64.2 & 28.9 & 7.9 & 5.7 & 0.9 & 1.5 \\
MED & 7.0 & 7.0 & 41.0 & 35.8 & 6.7 & 4.1 & 0.6 & 1.8 \\
Potted soil $^{\dagger}$ & 7.6 & - & 255.0 & - & 9.1 & - & 1.0 & - \\
\hline
\end{tabular}

$\dagger$ Final values for this soil was variable according to the experiment for which it was used.

There is a positive correlation $(\mathrm{r}=0.80)$ between the AMRC and the change in $\mathrm{Zn}$ concentrations $(\Delta \mathrm{Zn})$ in the soil (Fig. 3). The highest $\Delta \mathrm{Zn}$ was found with the highest AMRC while the lowest $\Delta \mathrm{Zn}$ was found in the soil samples from control pots where the plants were absent. Jeffries (1987) observed that AM has improved productivity in soils of low fertility. They can be particularly important for increased uptake of slowly diffusing ions such as $\mathrm{PO}_{4}{ }^{3-}$ (Jacobsen et al. 1992); immobile nutrients such as $P$, $\mathrm{Zn}$, and $\mathrm{Cu}$ (Lambert et al. 1979; George et al. 1994) and heavy metals such as Cd (Guo et al. 1996; Liao et al. 2003). Krishna and Bagyaraj (1984) reported that inoculation of AM (G. fasciculatum (Thaxt.) Gerd. \& Trappe emend. C. Walker \& Koske) in peanut, increased uptake of Fe, Mn, and Zn. Marschner and Dell (1994), in a review on nutrient uptake in mycorrhizal symbiosis emphasized that AM fungi delivered up to $25 \%$ of the plant's $\mathrm{Zn}$ requirement. In this study, AMRC and plant Zn showed a positive correlation $(r=0.89)$. The highest amounts of plant Zn (4.8-6.2 $\mathrm{mgkg}^{-1}$ ) were recorded in sesame and wal rubber where the AMRCs were the highest (62.8-76.8\%), while the lowest plant Zn (3.2-3.9 $\mathrm{mgkg}^{-1}$ ) was recorded in chilli, tomato, kurakkan, and balathana where the AMRCs were the lowest (5.4-15.7\%) (Fig. 3). As with P, the overall soil available $\mathrm{Zn}$ decreased with time in the presence of respective plant species (Table 8), while the levels of plant $\mathrm{Zn}$ increased with time, indicating that $\mathrm{Zn}$ is mobilized from the soil and is ending up in the plant material (Fig. 3). Therefore, it is possible to assume that at the tested site in the DZ of Sri Lanka, AM associations of plants (crop \& weed species) can be associated with significant improvements in the uptake of less mobile soil nutrients like $P$ and Zn. 

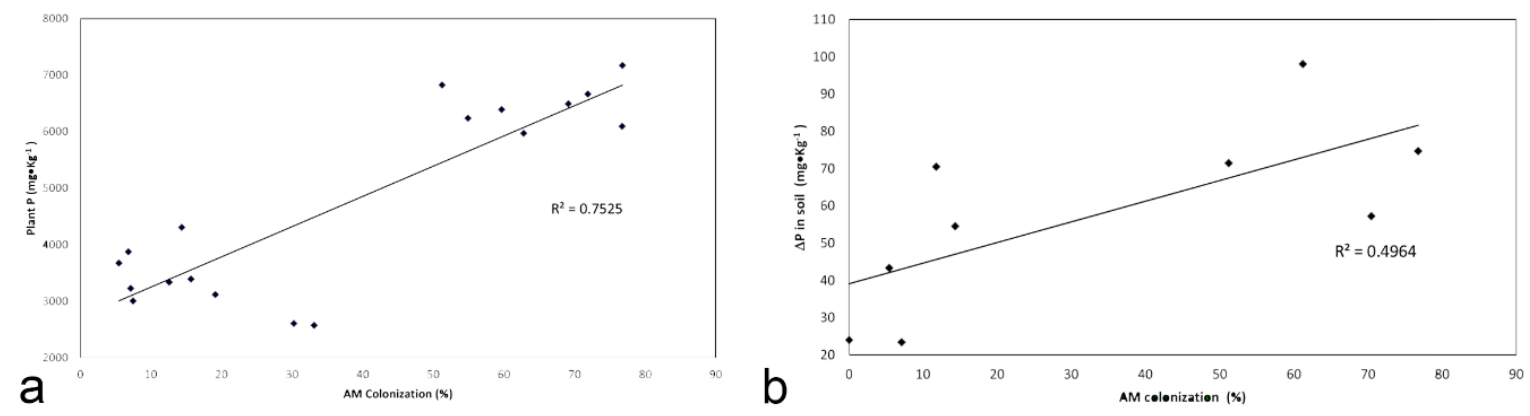

Figure 2: Relationships between AMRC with plant $\mathrm{P}$ and depletion of soil P levels. a) plant $\mathrm{P}$ vs. AMRC, b) soil $\triangle \mathrm{P} v s$. AMRC.

The AMSCs that survived in DZ soils during the dry season in Anuradhapura depended on the type and duration of land management. At the less-managed sites of Kiralogama and Puliyankulama, the lower spore counts of the dry season, built up with the onset of rains, at a rapid rate initially, suggesting that within 1012 weeks into the rain, AMSCs can reach full potential. Sites such as Medawachchiya, where there was continuous attention to traditional

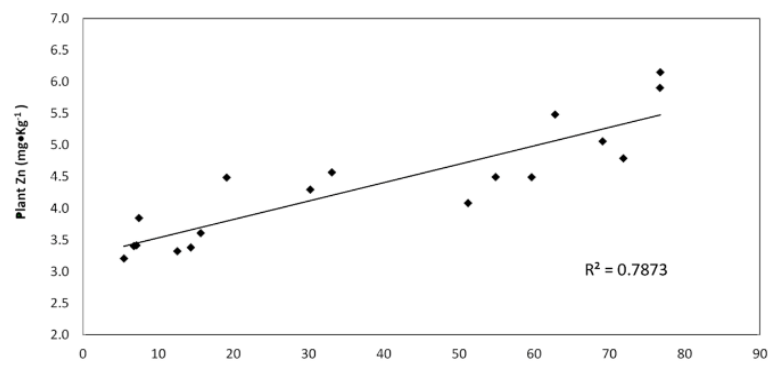

a

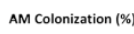

cultivation practices, had the most sustained AM spore abundance and activity. Percent AMRC was positively correlated with a drop-in $\mathrm{P}(\Delta \mathrm{P})$ and $\mathrm{Zn}$ $(\Delta \mathrm{Zn})$ concentrations in soil, coupled with significant increases in both plant $P$ and $\mathrm{Zn}$. Thus, while $\mathrm{P}$ and $\mathrm{Zn}$ were reduced in the soil during the study period, they appeared to have been taken up by the plants in proportion to the amount of AMRCs.

Figure 3: Relationships between AMRC with plant Zn and depletion of soil Zn levels. a) plant Zn levels vs. AMRC, b) soil $\Delta \mathrm{Zn} v s$. AMRC.

The build-up of AM spores in soil can also be significantly influenced by the

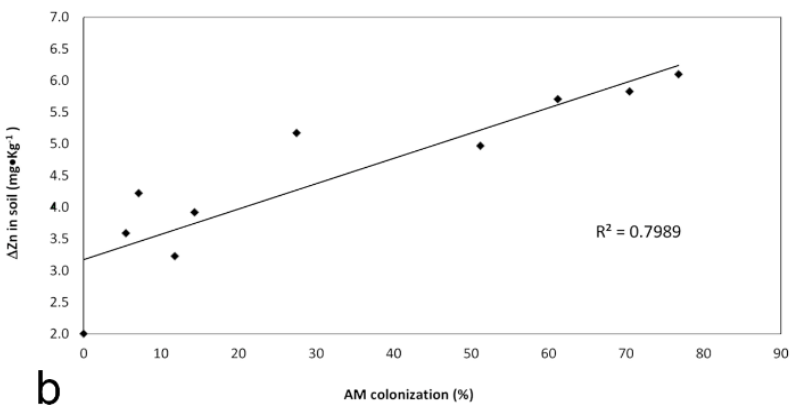

associated vegetation, both weed and crop plants, where plant species and 
varieties can influence their sustenance. The highest AMRC in crops was observed in Sesame (var. Mali) and bitter gourd (var. Black), while the highest AMRC in weeds was observed in wal rubber and akmella. These suggest that crop species/varieties that have a higher affinity with AM can be usefully deployed in the integrated nutrient management of DZ agricultural production. For example, Sesame and Bitter gourd could be utilized during the growing season or just prior to leaving the land fallow as a means to enhance AM populations. Wal rubber and akmella could be promoted during periods of fallow to help sustain AM populations for the upcoming growing season, thus providing a potentially cost-effective means of inoculating fields with beneficial AM and reduce dependence on chemical fertilizers at least in some proportion.

Further studies are required to confirm the influence of Mycorrhizae on crop yield. It should be noted that any pesticide (herbicides, fungicides, broadspectrum biocides) that affect the host plant or the soil microflora, is bound to affect the sustenance of mycorrhizal fungi. Thus, the development of more integrated land management practices, where the benefits of AM soil fungi can be sustained alongside a well-balanced approach of chemical additives, could be the option for improving future crop yields while keeping an eye on human health.

\section{Conclusions}

Dry zone (DZ) soils (Anuradhapura District) harbour reasonable counts of AM spores even during the drier months. Their abundance under DZ land management practices has increased with the progress of seasonal rainfall and crop/weed growth. The presence of AM under DZ land management practices are sustained by the presence of weeds during fallow periods. There are crop varieties and weed species that are more favourable for arbuscular mycorrhizal (AM) associations. Some crop and weed species, due to their relationship with AM can help improving the uptake of less mobile soil nutrients like P and Zn.

\section{Acknowledgements}

This work was supported in part by the CAFNR (College of Agriculture, Food and Natural Resources) International Program, The University of Missouri, Columbia, MO [Incentive Fund 2014], and in part from the funds made available by the Department of Plant 
Sciences, Faculty of Agriculture, Rajarata University of Sri Lanka.

Conflicts of interest: The authors have no conflicts of interest regarding this publication.

\section{References}

Alloush G A, Zeto S K, Clark R B (2000) Phosphorus source, organic matter, and arbuscular mycorrhiza effects on growth and mineral acquisition of chickpea grown in acidic soil. J Plant Nutr 23:1351-1369.

Barea J M, Azcon-Aguilar C (1983) Mycorrhizas and their significance in nodulating nitrogen-fixing plants. Adv Agron 36: 1-54.

Bellgard S E (1993) Soil disturbance and infection of Trifolium repens roots by vesicular arbuscular mycorrhizal fungi. Mycorrhiza 3:25-29.

Berruti A, Lumini E, Balestrini R, Bianciotto V (2016) Arbuscular mycorrhizal fungi as natural biofertilizers: let's benefit from past successes. Front Microbiol 6:1559.

Bhale U N, Bansode S A, Singh S (2018) Multifactorial role of arbuscular mycorrhizae in agroecosystem in Gehlot P, Singh J (Eds.) Fungi and their role in sustainable development: Current Perspectives 2018. Springer, Singapore.

Bolan N S (1991) A critical review on the role of mycorrhizal fungi in the uptake of phosphorus by plants. Plant Soil 134:189-207.

Brundrett M C, Abbott L K (1994) Mycorrhizal fungal propagules in the Jarrah forest. I. Seasonal study of inoculum levels. New Phytol 127:539546.

Burchfield E K, Gilligan J (2016). Agricultural adaptation to drought in the Sri Lankan dry zone. Appl Geogr 77:92100.

Chandra S, Kehri H K (2006) Biotechnology of VA Mycorrhiza: Indian scenario. New India Publishing 413.

Cress W A, Throneberry G O, Lindsey D L (1979) Kinetics of phosphorus absorption by mycorrhizal and nonmycorrhizal tomato roots. J Plant Physiol 64:484-487.

Cseke L J, Wullschleger S D, Sreedasyam A, Trivedi G, Larsen P, Collart F R (2013) Chapter 12. Carbon Sequestration in Kole C (Ed.), Genomics and Breeding for Climate-Resilient Crops 2013. Springer, Germany. 
Darmakeerthi R S, Indraratne $\mathrm{S} P$, Kumaragamage D (2007) Manual of soil sampling and analysis. Special publication of J Soil Sci Soc Sri Lanka 10:45-46, 69-71, 93-96, 115-116.

Day L D, Sylvia, D M, Collins M E (1987) Interactions among vesicular arbuscular mycorrhizae, soil and landscape position. Soil Sci Soc Am J 51:635-639.

Douds D D, Galvez L, Janke R, Wagoner P (1995) Effect of tillage and farming system upon populations and distribution of vesicular arbuscular mycorrhizal fungi. Agric Ecosyst Environ 52:111-118.

Ellouze W, Hamel C, Vujanovic V, Gan Y, Bouzid S, St-Arnaud M (2013) Chickpea genotypes shape the soil microbiome and affect the establishment of the subsequent durum wheat crop in the semiarid North American Great Plains. Soil Biol Biochem 63:129-141.

Evans D G, Miller M H (1988) Vesiculararbuscular mycorrhizas and the soil disturbance-induced reduction of nutrient absorption in maize. I. Causal relations. New Phytolo 110:67-74.

Fitter A H, Merryweather J W (1992) Why are some plants more mycorrhizal than others? An ecological enquiry in Read D J, Lewis D H, Fitter AH, Alexander I J (Eds.), Mycorrhizas in ecosystems, CAB International, Wallingford, UK, pp. 26-36.

Fontanet X, Estaun V, Camprubi A, Calvet C (1998) Fungicides added to potting substrate affect mycorrhizal symbiosis between a Peach Almond rootstock and Glomus sp. Hortic Sci 33:1217-1219.

George E, Romheld V, Marschner H (1994) Contribution of mycorrhizal fungi to micronutrient uptake by plants in Monthey J A, Crowley D E, Luster D G (Eds.), Biochemistry of metal micronutrients in the rhizosphere. CRC Press, Boca Raton, FL, pp. 93-109.

Gregory P J (2006) Roots, rhizosphere, and soil: the route to a better understanding of soil science. Eur J Soil Sci 57:2-12.

Guo Y, George E, Marschner H (1996) Contribution of an arbuscular mycorrhizal fungus to uptake of cadmnium and nickel in bean by maize plants. Plant Soil 184:195-205.

Haas J H, Bar-Yosef B, Krikun J, Barak R, Markovitz T, Kramer S (1987) Vesiculararbuscular mycorrhizal fungus 
infestation and phosphorus fertilization to overcome pepper stunting after methyl bromide fumigation. Agron J 79:905-910.

Habate M, Manjunath A (1991) Categories of vesicular-arbuscular mycorrhizal dependency of host species. Mycorrhiza 1:3-12.

Habte M (1989) Impact of simulated erosion on the abundance and activity of indigenous vesicular-arbuscular mycorrhizal endophytes in an oxisol. Biol Fert Soils 7:164-167.

Hayman D S (1983) The physiology of vesicular-arbuscular endomycorrhizal symbiosis. Can J Bot 61:944-963.

Heap A J, Newman E I (1980) The influence of VA Mycorrhizae on phosphorus transfer between plants. New Phytol 85:173-179.

Heckman J R, Angle J S (1987) Variation between soybean cultivars in vesiculararbuscular mycorrhiza fungi colonisation. Agron J 79:428-430.

Hijri M, Redecker D, Petetot J A, Voigt K, Wöstemeyer J, Sanders I R (2002) Identification and isolation of two ascomycete fungi from spores of the arbuscular mycorrhizal fungus
Scutellospora castanea. Appl Environ Microbiol 68:4567-4573.

Ianson D C, Allen M E (1986) The effects of soil texture on extraction of vesiculararbuscular mycorrhizal fungal spores from arid sites. Mycologia 78:164-168.

Islam R, Ayanaba A, Sanders F E (1980) Response of cowpea (Vigna unguiculata) to inoculation with VA-Mycorrhizal fungi and to rock phosphate fertilization in some unsterilized nigerian soils. Plant Soil 54:107-117.

Jacobsen I, Abbott L K, Robson A (1992) External hyphae of vesicular arbuscular mycorrhizal fungi associated with Trofoluim subterraneum L. I. Spread of hyphae and phosphorus inflow into roots. New Phytol 120:371-380.

Jayasumana C, Gunatilake S, Senanayake P (2014) Glyphosate, hard water and nephrotoxic metals: are they the culprits behind the epidemic of chronic kidney disease of unknown etiology in Sri Lanka? Int J Environ Res Public Health 11:2125-2147.

Jeffries P (1987) Use of mycorrhiza in agriculture. Crit Rev Biotechnol 5:319357. 
Justina J T, Khan N, Anwer W, Suliman R (2012) Mycorrhizal association in some weeds of curcuma longa fields of District Kasur, Pakistan. Pak J Weed Sci Res 18:331-335.

Kaushal S (2002) Influence of edaphic factors on VAMF spore population and root colonisation in Acacia. Bharathidsan, University, Tiruchirapali, Tamil Nadu, India, 155 pp.

Klopatek C C, Debano L F, Klopatek J M (1988) Effects of simulated fire on vesicular-arbuscular mycorrhizae in pinyon-juniper woodland soil. Plant Soil 109:245-249.

Koide R T, Mooney H A (1987) Spatial variation in inoculum potential of vesicular arbuscular mycorrhizal fungi caused by formation of gopher mounds. New Phytol 107:173-182.

Krishna K R, Bagyaraj D J (1984) Growth and nutrient uptake of peanut inoculated with mycorrhizal fungus Glomus fasciculatum compared with uninoculated ones. Plant Soil 17:405408.

Krishna K R, Shetty K G, Dart P J, Andrews D J (1985) Genotype dependent variation in mycorrhizal colonisation and response to inoculation of pearl millet. Plant Soil 86:113-125.

Lambert D H, Baker D E, Cole H (1979) The role of mycorrhizae in the interactions of phosphorus with zinc, copper and other elements. Soil Sci Soc Am J 43:976-980.

Larsen P E, Sreedasyam A, Trivedi G, Desai S, Dai Y, Cseke L J, Collart F R (2016) Multi-omics approach identifies molecular mechanisms of plant-fungus mycorrhizal interaction. Front Plant Sci 6:1061.

Lejon D P H, Chaussod R, Ranger J, Ranjard L (2005) Microbial community structure and density different tree species in an acid forest. Microb Ecol $50: 614-625$.

Liao J P, Lin X G, Cao Z H, Shi Y Q, Wong M $\mathrm{H}$ (2003) Interactions between arbuscular mycorrhizae and heavy metals under sand culture experiment. Chemosphere 50:847-853.

Lowenfels J, Lewis W (2010) Teaming with microbes: The organic gardener's guide to the soil food web. Timber Press, Portland, Oregon.

Mackay J E, Macdonald L M, Smernik R J, $\begin{array}{lllll}\text { Cavagnaro } & \mathrm{T} & \mathrm{R} & \text { (2017) } & \text { Organic }\end{array}$ 
amendments as phosphorus fertilisers: Chemical analyses, biological processes and plant $\mathrm{P}$ uptake. Soil Biol Biochem 107:50-59.

Mala W J, Kumari I S, Sumanasena H A, Nanayakkara C M (2010) Effective spore density of Glomus mosseae, arbuscular mycorrhiza (AM), for inoculation of rooted cuttings of black pepper (Piper nigrum Linn.). Agric Res 21:189-197.

Mansfeld G K, Larsen J, Bodker L (2002) Bacterial populations associated with mycelium of the arbuscular mycorrhizal fungus Glomus intraradices. FEMS Microbiol Ecol 41:133-140.

Marschner H, Dell B (1994) Nutrient uptake in mycorrhizal symbiosis. Plant Soil 159:89-102.

Miller R M (1979) Some occurrences of vesicular-arbuscular mycorrhizal in natural and disturbed ecosystems of the Red Desert. Can J Bot 57:619-623.

Nopamornbodi O, Thumsurakul S, Vasuvat Y (1987) Survival of VA mycorrhizal fungi after paddy rice in Sylvia D M, Hung L L, Graham J H (Eds.) Mycorrhizae in the next decade, practical applications and research priorities 1987. Institute of Food and Agriculture Sciences, University of Florida,
Gainesville, pp. 53.

Pagano M C, Utida M K, Gomes E A, Marriel I E, Cabello M N, Scotti M R (2011) Plant-type dependent changes in arbuscular mycorrhizal communities as soil quality indicator in semi-arid Brazil. Ecol Indic 11:643-650.

Palipane J B, Bandara J M R S (1985) Influence of vesicular-arbuscular mycorrhizal fungi on the growth of coffee and cacao seedlings. Sri Lanka Journal of Agricultural Science 22:73-79.

Panabokke C R (1996) Soils and agroecological environments of Sri Lanka. Colombo, Sri Lanka. NARESA Natural resources series no. 2 xvi, 220.

Pathirana B K W, Yapa P N (2020) Evaluation of different carrier substances for the development of an effective pelleted biofertilizer for rice (Oryza sativa L.) using co-inoculated bacteria and arbuscular mycorrhizal fungi. Asian J Biotechnol Bioresour Technol 6:1-10.

Perry D A, Molina R, Amaranthus M P (1987) Mycorrhizae, mycorrhizospheres and reforestation: current knowledge and research needs. Can J Forest Res 17:929-940.

Phillips J H, Hayman D S (1970) 
Improved procedures for clearing roots and staining parasitic and vasicular arbuscular mycorrhizal fungi for rapid assessment of infection. Trans Brit Mycol Soc 55:158-161.

Pigott C D (1982) Survival of mycorrhizas formed by Centroccocum geophilum in dry soils. New Phytol 92:513-517.

Plenchete C A, Fortin A, Forlan N (1983) Growth response of several plant species to mycorrhiza in a soil of moderate Pfertility. I. Mycorrhizae under field conditions. Plant Soil 70:199-203.

Powell C L (1980) Mycorrhizal infectivity of eroded soils. Soil Biol Biochem 12:247-250.

Rives C S, Bajwa M I, Liberia A E, Miller R M (1980) Effects of topsoil storage during surface mining on the viability of VA mycorrhiza. J Soil Sci 129:253-257.

Smith A P, Marín-Spiotta E, de Graaff M A, Balser T C (2014) Microbial community structure varies across soil organic matter aggregate pools during tropical land cover change. Soil Biol Biochem 77:292-303.

Soka G E, Ritchie M E (2018) Arbuscular mycorrhizal spore composition and diversity associated with different land uses in a tropical savanna landscape.
Appl Soil Ecol 125:222-232.

Thompson J P (1987) Decline of vesicular-arbuscular mycorrhizae in long fallow disorder of field crops and its expression in phosphorus deficiency of sunflower. Aust J Agric Res 38:847-67.

Troeh Z I, Loynachan T E (2003) Endomycorrhizal fungal survival in continuous corn, soybean and fallow. Agronomy 95:224-230.

Victor T, Delpratt N, Cseke S B, Kirchner G, Miller L M, Cseke L J (2017) Imaging nutrient distribution in the rhizosphere using FTIR-Imaging. Anal Chem 89:4831-4837.

Vivekanandan M, Fixen P E (1991) Cropping systems effect on mycorrhizal colonisation, early growth, and phosphorus uptake of corn. Soil Sci Soc Am J 55:136-140.

Wallace L L (1987) Effects of clipping and soil compaction on growth, morphology and mycorrhizal colonisation of Schizachyzum scoparium, a C4 bunchgrass. Oecologia 72:423-428.

Wicklow-Howard M (1989) The occurrence of vesicular-arbuscular mycorrhizae in burned areas of the Snake River Birds of Prey area, Idaho. Mycotaxon 34:253-257. 